\title{
Effectiveness of the use of hearing aids in the rehabilitation of patients with tinnitus:
}

\section{a systematic review}

\author{
Efetividade do uso do AASI na reabilitação do paciente com zumbido: uma revisão sistemática \\ Efectividad del uso de audífonos en la rehabilitación de pacientes con tinnitus: una revisión sistemática
}

Received: 12/07/2021 | Reviewed: 12/13/2021 | Accept: 12/20/2021| Published: 01/03/2022

\author{
Ana Paula de Moraes \\ ORCID: https://orcid.org/0000-0001-9978-1991 \\ Instituto de Estudos Avançados em Audição, Brazil \\ E-mail: paula.a.moraes@ hotmail.com \\ Taíssa Cristina Xavier de Luna \\ ORCID: https://orcid.org/0000-0001-5966-0650 \\ Instituto de Estudos Avançados em Audição, Brazil \\ E-mail: taissa_luna@yahoo.com.br \\ Teresa Maria Momensohn dos Santos \\ ORCID: https://orcid.org/0000-0003-4751-0721 \\ Instituto de Estudos Avançados em Audição, Brazil \\ E-mail: taissa_luna@yahoo.com.br
}

\begin{abstract}
Introduction: Tinnitus is a symptom reported by the individual as a sound sensation, perceived in the ears or head, continuously or intermittently without external source of stimulation. This alteration has variable causes and may be associated with patients with hearing loss or normal hearing. Among main methods cited as treatment possibilities, hearing aids has been presented as a widely used resource. Objective: To carry out an integrative literature review on the effectiveness of hearing aids in rehabilitation of patients with tinnitus. Method: A search for articles was carried out in electronic databases: PubMed, Scielo, Scopus, Lilacs, Web of Science, with publication date from 2000 to 2020. Results: The sample consisted of 16 works where all concluded that somehow, in most cases, hearing aids associated or not with other resources used in treatment, contributes to a satisfactory result in improvement or disappearance of the symptom. Seven of sixteen articles related hearing aids to some type of guidance. The combination of these two factors could be considered an excellent combination as it favors the reduction of tinnitus sensation relatively quickly and efficiently. None of the articles analyzed showed an opposite or unsatisfactory result regarding its use.
\end{abstract}

Keywords: Tinnitus; Hearing Aids; Hearing loss; Quality of life; Tinnitus rehabilitation.

\section{Resumo}

Introdução: Zumbido é um sintoma relatado pelo indivíduo como uma sensação sonora, percebida nos ouvidos ou na cabeça, de forma contínua ou intermitente sem que haja a presença de fonte externa de estimulação. Essa alteração tem causa variável e pode estar associada a pacientes com perda auditiva ou com audição normal. Dentre os principais métodos citados como possibilidades de tratamento, o AASI tem sido apresentado como um recurso bastante utilizado. Objetivo: Realizar revisão integrativa da literatura sobre a efetividade do uso do AASI na reabilitação do paciente com zumbido. Método: Foi realizada uma busca de artigos nas bases de dados eletrônicas: PUBMED/MEDLINE, ISI Web of Knowledge, LILACS e SciELO, com data de publicação de 2000 a 2020. Resultados: A amostra foi composta por 16 trabalhos onde todos concluíram que de alguma forma, na maior parte dos casos, o AASI associado ou não aos demais recursos utilizados no tratamento, colabora para um resultado satisfatório na melhora ou desaparecimento do sintoma. Sete dos dezesseis artigos relacionaram o AASI a algum tipo de orientação. A junção desses dois fatores pôde ser considerada uma excelente combinação pois favorece a redução da sensação do zumbido de forma relativamente rápida e eficiente. Nenhum dos artigos analisados mostrou um resultado contrário ou insatisfatório com relação a utilização do mesmo.

Palavras-chave: Zumbido; Auxiliar de audição; Perda auditiva; Reabilitação do zumbido.

\section{Resumen}

Introducción: El tinnitus es un síntoma informado por el individuo como una sensación sonora, percibida en los oídos o la cabeza, de forma continua o intermitente, sin la presencia de una fuente externa de estimulación. Esta alteración tiene causas variables y puede estar asociada a pacientes con hipoacusia o con audición normal. Entre los principales métodos citados como posibilidades de tratamiento, el audífono se ha presentado como un recurso ampliamente utilizado. Objetivo: Realizar una revisión integradora de la literatura sobre la efectividad del uso de audífonos en la 
rehabilitación de pacientes con acúfenos. Método: Se realizó una búsqueda de artículos en bases de datos electrónicas: PUBMED / MEDLINE, ISI Web of Knowledge, LILACS y SciELO, con fecha de publicación de 2000 a 2020. Resultados: La muestra estuvo conformada por 16 trabajos donde todos concluyeron que de alguna manera, en la mayoría casos, el audífono asociado o no a los demás recursos utilizados en el tratamiento, contribuye a un resultado satisfactorio en la mejoría o desaparición del síntoma. Siete de los dieciséis artículos relacionaban el audífono con algún tipo de orientación. La combinación de estos dos factores podría considerarse una combinación excelente ya que favorece la reducción de la sensación de tinnitus de forma relativamente rápida y eficaz. Ninguno de los artículos analizados mostró un resultado contrario o insatisfactorio en cuanto a su uso.

Palabras clave: Acúfeno; Audífonos; Pérdida auditive; Calidad de vida.

\section{Introduction}

Also known as buzzing, tinnitus is a symptom reported by the individual as a sound sensation, which can be characterized as a noise similar to the noise of rain, sea, running water, bells, insects, whistles, wheezing, pulse and others, without an external source of stimulation. This sensation can be perceived in ears or in the head, continuously or intermittently and in different intensities (Padilha, 2006).

Tinnitus can occur unilaterally or bilaterally. Tinnitus occurs more frequently in the context of concurrent sensorineural hearing loss, particularly among patients with annoyance tinnitus and without auditory pathology (Tunkel, 2014).

Tinnitus is an alteration that is often associated with hearing loss; however, it can also occur in people with normal hearing. Its cause is variable and not always apparent, and may be triggered by factors such as otological diseases, cardiovascular and dental disorders, metabolic, neurological, psychiatric disorders, medications side effects, ototoxic drugs, caffeine, nicotine, alcohol, among others. These factors can present in an isolated or joint way in the same individual (Knobel, 2000).

The lack of control and the continuous presence of this symptom can seriously damage the individual's quality of life with this change. It can often affect four different primary functions: thoughts and emotions, hearing, sleep, and concentration (Tyler, et al., 2014) (4). It is common, for example, in addition to natural discomfort caused by the noise presence, for patient complain of difficulty in speech understanding. This difficulty, compromises communication in general, making patient's daily life activities more difficult due to these and other factors, from a slight irritation to psychological and physical disorders in form of anxiety, depression, lack of concentration, insomnia and, in more severe cases, even suicide (Silva et al., 2007).

It is a multifactorial origin symptom, with a complex pathophysiology and not completely elucidated, tinnitus is a condition of hard analysis, measured and treated (Rosa et al., 2012). So far, there hasn't been found a single effective treatment able to eliminate it altogether yet.

It is important to patients who have this condition pass firstly through a good research with professionals in quest to discover etiological possibilities that culminated in appearance of this complaint, so based on it, it is possible to map out the best strategy of treatment for each case (Ferrari, 2003).

According to Padilha (2006), even with good research, there are frequent cases where it is not possible to identify the causing agent of tinnitus, making the symptom cure or elimination even more challenging. However, even if it is not possible to eliminate it completely, strategies were created with the objective of alleviating the inconvenience and consequently damage caused by it.

In literature, the main methods mentioned as treatment possibilities for tinnitus are: use of medication, acupuncture, electrical stimulation, cognitive therapy and sound therapy with use of an hearing aids for amplification - when necessary masking and habituation (Suzuki et al., 2016).

Among existing possibilities, hearing aids are widely used in tinnitus retraining therapy (TRT). TRT is a therapy that combines counseling with sound therapy (sound generators or hearing aids) to promote tinnitus habituation (Jastreboff and 
Jastreboff, 2000). Habituation works on the brain's ability to ignore neutral, meaningless stimuli (Hooldefer et al., 2010). This treatment model was created by Pawel Jastreboff in 1990, who found that, although most cases are initially related to some cochlear alteration, this is not the only important factor in determining tinnitus severity. Normally, it only acts as a trigger for processes sequence within nervous system that involves auditory and non-auditory pathways, including limbic system, which is responsible for emotional reactions. Thus, it can be understood that the meaning that the sound acquires and represents for that individual is as important as its psychoacoustic characteristics (Sanchez et al., 2002).

In conjunction with practice of habituation, hearing aids with a sound generator (SG) have been a good ally in treatment of individuals with this alteration associated or not with hearing loss (HL). Henry et al (2006) recommended the use of combined instruments (amplification and noise generator in the same device) for a combined benefit of amplification and constant broadband noise to achieve this enhanced sound stimulation. (12). This process, in turn, is based on stimulating patient's ear in presence of sounds - broadband, music or any other spectrally modified sound - that are constantly emitted by the device in a controlled manner, in order to reduce hypersensitivity in silence and provide relief from it. The difference is that in cases where there is no hearing loss, only the sound generator will be activated, and in cases where there is a deficiency, in addition to the generator, the device will be programmed to amplify the sound according to the degree of the subject's loss (Rocha \& Mondelli, 2017).

In conjunction with counseling, hearing aids, sound generators, and combined devices (sound generation in a device) currently constitute first line treatment for those who have audiology tinnitus (Brennan Jones, 2020).

Taking into account that hearing aid has been presented as a technological resource to rehabilitate people with tinnitus, here is a question: is the hearing aid really efficient for the rehabilitation of patients with tinnitus?

To answer the question, this study aims to carry out an integrative literature review on the effectiveness of using hearing aids in the rehabilitation of patients with tinnitus.

\section{Methodology}

The integrative literature review is a method that aims to synthesize results obtained in previous research on an investigated topic, in a systematic, orderly and comprehensive way, in order to establish conclusions based on the critical evaluation of the research found.

\subsection{Eligibility criteria:}

To consider the eligibility of studies to be included/excluded in this review, the acronym "PICOS" was used as shown in Figure 1.

Figure 1. Search strategy with PICO strategy;

\begin{tabular}{|c|c|}
\hline Population & $\begin{array}{l}\text { Adults over } 18 \text { years of age with normal hearing or with hearing loss and tinnitus; articles in Portuguese, English or } \\
\text { Spanish; published from } 2000 \text { onwards. }\end{array}$ \\
\hline Intervention & Have undergone rehabilitation or therapy with hearing aid; evaluation of the use of hearing aid as tinnitus therapy. \\
\hline Comparative & Comparison with other rehabilitation methods; group control. \\
\hline Outcome & Results presented by the authors of each article. \\
\hline $\begin{array}{l}\text { Electronic } \\
\text { Databases: }\end{array}$ & PUBMED/MEDLINE, ISI Web of Knowledge, LILACS e SciELO \\
\hline $\begin{array}{l}\text { Eligibility } \\
\text { Criteria }\end{array}$ & $\begin{array}{l}\text { Inclusion: Adults over } 18 \text { years of age with normal hearing or with hearing loss and tinnitus; articles in Portuguese, } \\
\text { English or Spanish; published from } 2000 \text { onwards. Have undergone rehabilitation or therapy with hearing aid; } \\
\text { evaluation of the use of hearing aid as tinnitus therapy. } \\
\text { Exclusion: Literature review works, opinions, case reports; editorial and/or letter to the editor were excluded. }\end{array}$ \\
\hline
\end{tabular}




\subsection{Information sources and search strategy}

Studies with publication date from 2000 to 2020 were selected, as well as studies that included in title or abstract the Health Sciences Descriptors (DeCS): Zumbido, Acúfeno, Auxiliar de Audição e Reabilitação, as well as its equivalents in English (Tinnitus, Hearing Aid and Rehabilitation) and Spanish (Zumbido, Aparato Auditivo and Rehabilitación). In addition to the descriptors, this search was also performed for their respective associated terms (word crossing).

To obtain these bibliographic data, a search for articles was performed in following electronic databases: PUBMED/MEDLINE (Medical Literature Analysis), ISI Web of Knowledge (Institute for Scientific Information), LILACS (Latin American Literature in Health Sciences) and SciELO (Scientific Electronic Library Online).

\subsection{Inclusion Criteria}

As inclusion criteria, original research articles were selected, freely available in full format (open access), published in Portuguese, English or Spanish. The use of the descriptors and the associated terms mentioned above (and/e), published in indicated period, in the aforementioned databases, whose titles and abstracts were related to the topic of hearing aid as a rehabilitation method for individuals over 18 years old who presented tinnitus.

\subsection{Exclusion criteria}

Abstracts in conference proceedings, books, dissertations and theses were excluded from the review. Studies in which children and adolescents participated were not included, as well as studies that did not use hearing aids for tinnitus treatment.

\subsection{Selection process}

The articles selection was carried out in two phases. In phase 1, titles and abstracts of all references were independently reviewed. All articles that were not in the inclusion criteria were excluded. In phase 2, the complete reading of selected articles were independently analyzed. In case of disagreement, and when this was not resolved through discussion between the first and second reviewers, a third author was involved for the final decision (Figure 2).

Figure 2. Identification, screening and eligibility steps.

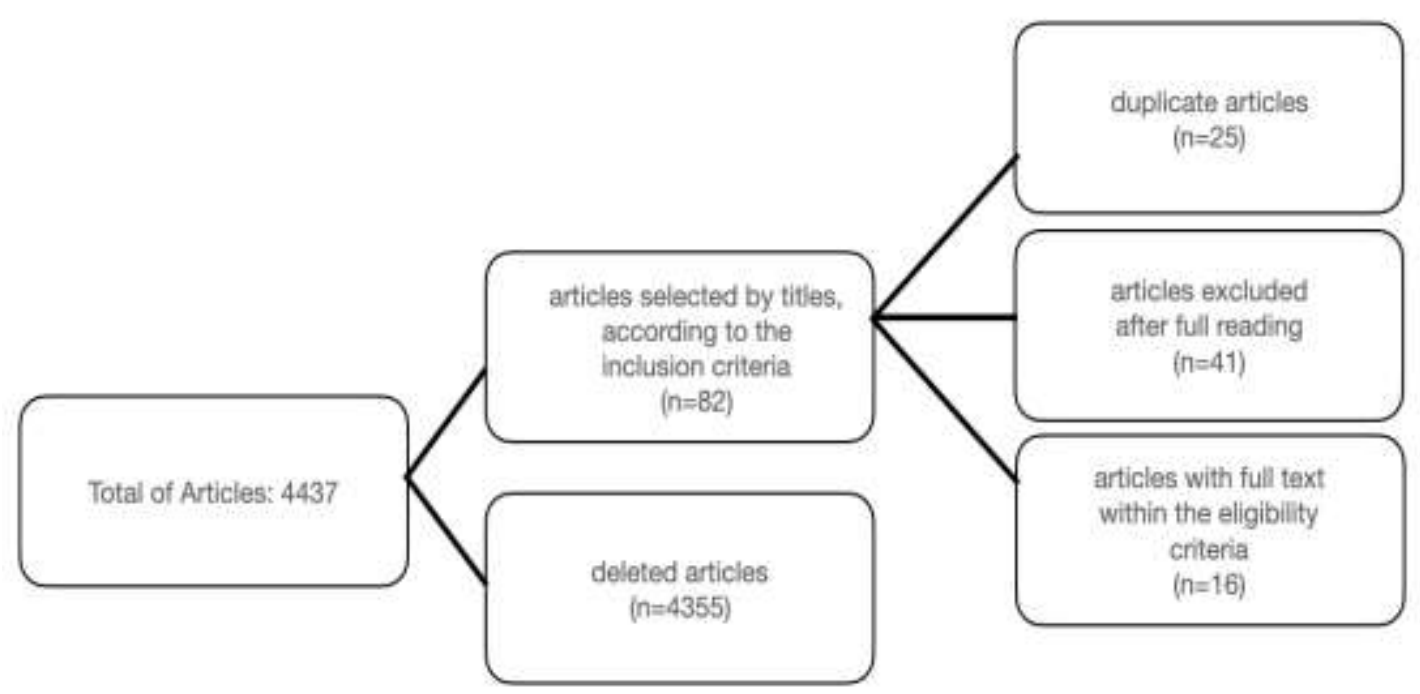

Source: Authors. 


\subsection{Data collection process}

Two reviewers collected information from the included studies, and this information was discussed. The collected data consisted of: study characteristics (authors, year of publication, country, study design), population characteristics (sample size, age group), evaluation characteristics (composition of control and intervention groups, parameters of interest, outcome assessment method, index used for assessment), characteristics of the results (results presented in relation to the outcome) and main conclusions.

\subsection{Selection of studies}

Through the elaborated research strategy, a search was carried out in five databases, totaling 4,437 articles. Excluding articles that did not fit the criteria (4,355), 82 articles were selected for title and abstract reading. Of these articles, 25 were duplicate articles, 41 were excluded after full reading, resulting in 16 articles to carry out the integrative review.

\section{Results and Discussion}

After consulting databases and applying the search criteria, the final sample of this review consisted of 16 scientific works selected through the inclusion and exclusion criteria mentioned above.

Table1. Studies that demonstrate that the use of hearing aids combined with the sound generator can alleviate the symptoms of patients with tinnitus.

\begin{tabular}{|c|c|c|c|c|}
\hline & Authors, title and year & Objective & Type of Study, Evaluated group and Method & Outcome \\
\hline 1 & $\begin{array}{l}\text { Moura, L. O. S. D., } \\
\text { Iório, M. C. M., \& } \\
\text { Azevedo, M. F. D. } \\
\text { (2004) } \\
\text { A eficácia da adaptação } \\
\text { de prótese auditiva na } \\
\text { redução ou eliminação } \\
\text { do zumbido }\end{array}$ & $\begin{array}{l}\text { Verify hearing aid } \\
\text { fitting in reducing or } \\
\text { eliminating tinnitus in } \\
\text { patients with hearing } \\
\text { loss efficiency. }\end{array}$ & $\begin{array}{l}\text { Serial study. } \\
47 \text { individuals aged between } 32 \text { and } 88 \text { years old, with } \\
\text { tinnitus and mild to profound hearing loss, unilateral or } \\
\text { bilateral and sensorineural. A subjective assessment of } \\
\text { tinnitus was performed by means of acuphenometry, } \\
\text { followed by a follow-up of these patients for one year } \\
\text { after fitting the prosthesis in order to verify if there was } \\
\text { any improvement. }\end{array}$ & $\begin{array}{l}\text { There was an improvement in } \\
\text { tinnitus with the use of hearing aids } \\
\text { in } 87.2 \% \text { of the individuals, and in } \\
51 \% \text { of them, tinnitus disappeared } \\
\text { completely. }\end{array}$ \\
\hline 2 & $\begin{array}{l}\text { Henry J.A., T.L. Zaugg, } \\
\text { S. Griest, P.J. Jastreboff, } \\
\text { J.A. Vernon, C. Kaelin, } \\
\text { M.B. Meikle, K.S. } \\
\text { Lyons \&B.J. Stewart. } \\
\text { Portland, (2006) } \\
\text { Clinical trial to compare } \\
\text { tinnitus masking and } \\
\text { tinnitus retraining } \\
\text { therapy }\end{array}$ & $\begin{array}{l}\text { To evaluate the } \\
\text { effectiveness of } \\
\text { tinnitus masking (TM) } \\
\text { and tinnitus retraining } \\
\text { therapy (TRT) in } \\
\text { military personnel } \\
\text { with clinically } \\
\text { significant tinnitus. }\end{array}$ & $\begin{array}{l}\text { Clinical, comparative and prospective study. } \\
118 \text { military personnel with significant tinnitus, to the } \\
\text { point of justifying long-term treatment. Patients were } \\
\text { randomly separated into two groups; one would use the } \\
\text { TRT and the other would use the sound generator. The } \\
\text { TISI (Tinnitus Impact Screening Interview) and the } \\
\text { initial TRT questionnaire were applied, and } \\
\text { audiological and acuphenometry assessments were } \\
\text { carried out. In addition, before the 18-month treatment, } \\
\text { subjects completed service questionnaires, THI and } \\
\text { THQ (Tinnitus Handicap Questionnaire). Throughout } \\
\text { the treatment, subjects were evaluated at } 3,6,12 \text { and } 18 \\
\text { months. }\end{array}$ & $\begin{array}{l}\text { Both the TRT and the sound } \\
\text { generator are effective in treating } \\
\text { tinnitus. However, TRT was more } \\
\text { effective in patients with more } \\
\text { severe tinnitus, with results between } \\
12 \text { and } 18 \text { months of use, while the } \\
\text { sound generator was more effective } \\
\text { in the treatment of moderate } \\
\text { tinnitus, with apparent results from } \\
3 \text { to } 6 \text { months of treatment. }\end{array}$ \\
\hline 3 & 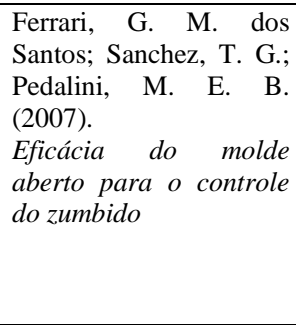 & $\begin{array}{l}\text { Assess the tinnitus } \\
\text { response to open } \\
\text { earmold hearing aids } \\
\text { with relief ventilation } \\
\text { in patients with mild to } \\
\text { severe symmetric } \\
\text { sensorineural hearing } \\
\text { loss after one month of } \\
\text { use. }\end{array}$ & $\begin{array}{l}\text { Crossover randomized blind clinical trial. } \\
50 \text { subjects, aged between } 25 \text { and } 89 \text { years, presence of } \\
\text { constant bilateral tinnitus and symmetrical bilateral } \\
\text { sensorineural hearing loss of any etiology, with } \\
\text { indication for hearing aids. } 26 \text { patients started using } \\
\text { open mold and } 24 \text { using relief ventilation. After } 30 \text { days } \\
\text { of testing, the mold was changed and the second one } \\
\text { was used for another } 30 \text { days. Tinnitus was assessed } \\
\text { qualitatively (with a closed question) and quantitatively } \\
\text { (numerical scale). }\end{array}$ & $\begin{array}{l}\text { In the short term, tinnitus } \\
\text { improvement with hearing aids does } \\
\text { not depend on the size of the mold } \\
\text { ventilation. }\end{array}$ \\
\hline 4 & 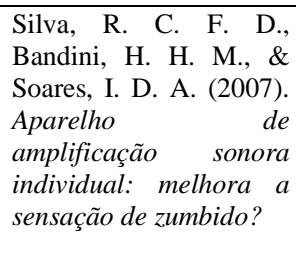 & $\begin{array}{l}\text { Observe whether the } \\
\text { use of sound } \\
\text { amplification, in } \\
\text { addition to improving } \\
\text { speech intelligibility, } \\
\text { can provide relief from } \\
\text { tinnitus. }\end{array}$ & $\begin{array}{l}\text { Descriptive study. } \\
21 \text { individuals, aged between } 35 \text { and } 88 \text { years old, } \\
\text { already hearing aid users, complaining of tinnitus and } \\
\text { sensorineural hearing loss. Participants answered a } \\
\text { questionnaire with open and closed questions related to } \\
\text { audiometry, tinnitus sensation, time of use, type of } \\
\text { hearing aid, mold and processing, compression system } \\
\text { and gain linearity. }\end{array}$ & $\begin{array}{l}\text { Most participants reported } \\
\text { immediate improvement in tinnitus } \\
\text { with the use of hearing aids, while a } \\
\text { small part reported no influence } \\
\text { whatsoever. }\end{array}$ \\
\hline 5 & $\begin{array}{l}\text { Parazzini M, Del Bo L., } \\
\text { Jastreboff M., Tognola }\end{array}$ & $\begin{array}{l}\text { To compare } \\
\text { effectiveness }\end{array}$ & $\begin{array}{l}\text { Randomized, prospective study. } \\
91 \text { individuals, who are between category } 1 \text { and }\end{array}$ & $\begin{array}{l}\text { The results showed a trend towards } \\
\text { a reduction in the THI parameters }\end{array}$ \\
\hline
\end{tabular}




\begin{tabular}{|c|c|c|c|c|}
\hline & $\begin{array}{l}\text { G. \&Ravazzani, P. } \\
\text { (2011). Open ear } \\
\text { hearing aids in tinnitus } \\
\text { therapy: An efficacy } \\
\text { comparison with sound } \\
\text { generators }\end{array}$ & $\begin{array}{l}\text { tinnitus retraining } \\
\text { therapy (TRT) with } \\
\text { SG or hearing aids in } \\
\text { tinnitus rehabilitation } \\
\text { for a group of subjects } \\
\text { who can be treated } \\
\text { with both approaches. }\end{array}$ & $\begin{array}{l}\text { category } 2 \text { (according to the Jastreboff classification), } \\
\text { with tinnitus for at least six months, bilateral and } \\
\text { symmetrical HL, who did not have Meniere or } \\
\text { associated external middle ear disease and who never } \\
\text { used hearing aids and TRT treatment. Randomly } \\
\text { divided into two groups: half with open-fit hearing aids } \\
\text { and half with GS. Participants initially underwent } \\
\text { complete audiological assessment, interviews, VAS and } \\
\text { THI, before and after therapy at } 3,6 \text { and } 12 \text { months. }\end{array}$ & $\begin{array}{l}\text { from the beginning of the } \\
\text { intervention until } 1 \text { year of therapy. } \\
\text { There was no significant difference } \\
\text { between the two groups. }\end{array}$ \\
\hline 6 & $\begin{array}{l}\text { Andersson, } \quad \text { G., } \\
\text { Keshishi, A., Baguley } \\
\text { D.M. (2011). } \\
\text { Benefits of hearing aids } \\
\text { in user with or without } \\
\text { tinnitus }\end{array}$ & $\begin{array}{l}\text { To assess the } \\
\text { prevalence of tinnitus } \\
\text { in hearing aid users, } \\
\text { investigate the benefit } \\
\text { of hearing aids in users } \\
\text { with and without } \\
\text { tinnitus, and assess the } \\
\text { association between } \\
\text { tinnitus discomfort and } \\
\text { the benefit of hearing } \\
\text { aids. }\end{array}$ & $\begin{array}{l}\text { Cross-sectional study. } \\
85 \text { individuals with sensorineural hearing loss who had } \\
\text { been using hearing aids for at least one year before the } \\
\text { research. Patients were divided into groups with tinnitus } \\
\text { and without tinnitus. The following were used: } \\
\text { Abbreviated Profile of Hearing Aid Benefit (APHAB), } \\
\text { answered with and without the use of hearing aids, in } \\
\text { addition to the THI. }\end{array}$ & $\begin{array}{l}\text { In general, all patients reported the } \\
\text { benefit of using the hearing aid, with } \\
\text { the exception of the APHAB } \\
\text { "Aversion to sounds" subscale, } \\
\text { which was more intensely perceived } \\
\text { in patients with tinnitus. }\end{array}$ \\
\hline 7 & $\begin{array}{l}\text { Oz, I., Arslan, F., Hizal, } \\
\text { E., Erbek, S. H., } \\
\text { Eryaman, E., Senkal, O. } \\
\text { A., \&Ozluoglu, L. N. } \\
\text { Turquia, (2013). } \\
\text { Effectiveness of the } \\
\text { combined hearing and } \\
\text { masking devices }\end{array}$ & $\begin{array}{l}\text { To evaluate the effect } \\
\text { of the combination of } \\
\text { the hearing device } \\
\text { with tinnitus masking } \\
\text { and medication } \\
\text { (betahistine) in the } \\
\text { treatment of patients } \\
\text { with tinnitus. }\end{array}$ & $\begin{array}{l}\text { Double-blind randomized controlled trial. } \\
21 \text { adult individuals with primary complaint of tinnitus. } \\
\text { Patients were randomly divided into two groups: Group } \\
1-12 \text { patients treated with betahistine (a drug used to } \\
\text { reduce/eliminate tinnitus), hearing aids and sound } \\
\text { generator. Group } 2-9 \text { patients treated only with } \\
\text { betahistine for } 3 \text { months. Audiological tests, } \\
\text { acuphenometry and subjective scores - EVA and Mini- } \\
\text { Tinnitus Questionnaire were performed in both groups. }\end{array}$ & $\begin{array}{l}\text { The study concluded that the } \\
\text { combination of the hearing device } \\
\text { with the masking broadband noise } \\
\text { associated with betaistatin proved to } \\
\text { be an effective method. Combined } \\
\text { treatment should be recommended } \\
\text { for patients with tinnitus and hearing } \\
\text { loss. }\end{array}$ \\
\hline 8 & $\begin{array}{l}\text { Mondelli, M. F. C. G., } \\
\text { Argentim, J. P., \& } \\
\text { Rocha, A. V. }(2016) \\
\text { Correlação } \\
\text { percepção de fala e } \\
\text { zumbido antes e após o } \\
\text { uso de amplificação }\end{array}$ & $\begin{array}{l}\text { Assess the degree of } \\
\text { tinnitus annoyance and } \\
\text { speech perception, } \\
\text { before and after } \\
\text { intervention with the } \\
\text { use of hearing aids }\end{array}$ & $\begin{array}{l}\text { Clinical trial-type intervention study. } \\
27 \text { individuals, older than } 18 \text { years, with mild to } \\
\text { moderate bilateral sensorineural hearing loss, } \\
\text { continuous bilateral tinnitus for at least six months and } \\
\text { no previous experience with amplification. The } \\
\text { individuals answered the anamnesis, the THI } \\
\text { questionnaire and performed the Hearing in Noise Test } \\
\text { (HINT), they were fitted with hearing aids and, after } \\
\text { three months, they performed the evaluations again. } \\
\text { The results were subjected to statistical analysis. }\end{array}$ & $\begin{array}{l}\text { There was an improvement in } \\
\text { relation to the degree of tinnitus } \\
\text { annoyance after the hearing aid } \\
\text { fitting. There was no significant } \\
\text { correlation between speech } \\
\text { perception, before and after using } \\
\text { hearing aids. }\end{array}$ \\
\hline 9 & $\begin{array}{l}\text { Suzuki F.A.B., Suzuki } \\
\text { F.A., Yonamine F.K., } \\
\text { Onishi E.T., Penido } \\
\text { N.O., (2016). } \\
\text { Eficácia da terapia } \\
\text { sonora em pacientes } \\
\text { com zumbido resistente } \\
\text { a tratamentos } \\
\text { anteriores: importância } \\
\text { dos ajustes }\end{array}$ & $\begin{array}{l}\text { Evaluate sound } \\
\text { generator effectiveness } \\
\text { with individual } \\
\text { adjustments to } \\
\text { alleviate tinnitus in } \\
\text { patients unresponsive } \\
\text { to previous treatments. }\end{array}$ & $\begin{array}{l}\text { Prospective study. } \\
10 \text { patients, aged between } 41 \text { and } 78 \text { years old, } \\
\text { complaining of continuous chronic tinnitus for over a } \\
\text { year, without improvement with drug therapies and } \\
\text { without specific treatment for tinnitus for at least } 3 \\
\text { months. Bilateral sound generators were used in the } \\
\text { Reach } 62 \text { or Mind } 9 \text { models for at least } 6 \text { hours a day } \\
\text { for } 18 \text { months. Patients were assessed at baseline and } \\
\text { after } 1,3,6,9,12,15 \text { and } 18 \text { months through the } \\
\text { following assessments: Otorhinolaryngological, } \\
\text { Audiological, Acuphenometry, Minimum Masking } \\
\text { Level (MML), Tinnitus Handicap Inventory (THI), } \\
\text { Visual Analogue Scale (EVA) and Hospital Anxiety } \\
\text { and Depression Scale (HADS). Sound generators were } \\
\text { adjusted at each visit as needed. }\end{array}$ & $\begin{array}{l}\text { There was an improvement in } \\
\text { quality of life (THI) with good } \\
\text { response to sound therapy with } \\
\text { personalized adjustments in patients } \\
\text { with tinnitus. Possibly, patients with } \\
\text { whistle-type tinnitus have a better } \\
\text { response. }\end{array}$ \\
\hline 10 & 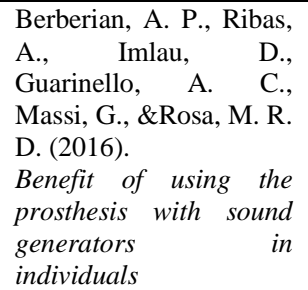 & $\begin{array}{l}\text { Describe the results } \\
\text { found in a group of } \\
\text { people who have } \\
\text { undergone tinnitus } \\
\text { treatment with sound } \\
\text { generators. }\end{array}$ & $\begin{array}{l}\text { Descriptive and experimental study. } 25 \text { individuals } \\
\text { with mild to moderately severe sensorineural hearing } \\
\text { loss of any configuration and complaining of bilateral } \\
\text { tinnitus, who used a hearing aid with a sound generator } \\
\text { in both ears for at least } 6 \text { months. The following were } \\
\text { analyzed: free field audiometry with and without the } \\
\text { use of devices; THI and EVA before and after } \\
\text { adaptation. }\end{array}$ & $\begin{array}{l}\text { After using hearing aids, the level of } \\
\text { discomfort decreased significantly. } \\
\text { Therefore, it is understood for this } \\
\text { study that the use of hearing aids } \\
\text { with a sound generator is a good } \\
\text { resource for the treatment of tinnitus } \\
\text { associated with hearing loss. }\end{array}$ \\
\hline 11 & $\begin{array}{lr}\text { Rocha, A.V., } & \& \\
\text { Mondelli, M.MF.C.G. - } \\
\text { São Paulo } & \text { (2017) } \\
\text { Gerador de rom } \\
\text { associado } \quad r \\
\text { aconselhamento } r o \\
\text { tratamento de zumbido: } \\
\text { avaliação da eficácia }\end{array}$ & $\begin{array}{l}\text { To verify } \\
\text { effectiveness of the } \\
\text { sound generator (SG) } \\
\text { associated } \\
\text { lounseling with } \\
\text { treatment of thinnitus in } \\
\text { individuals with and } \\
\text { without hearing loss in } \\
\text { relation to the } \\
\text { improvement of } \\
\text { discomfort and hearing } \\
\text { loss. }\end{array}$ & $\begin{array}{l}\text { Prospective, non-randomized, cohort clinical trial. } \\
30 \text { individuals complaining of bilateral chronic tinnitus, } \\
\text { divided into: Group 1 (G1) - } 15 \text { individuals with } \\
\text { tinnitus and normal hearing; Group } 2 \text { (G2) - } 15 \\
\text { individuals diagnosed with mild to moderate bilateral } \\
\text { sensorineural hearing loss and tinnitus. G1 was adapted } \\
\text { to SG and G2 adapted to SG and hearing aids. The } \\
\text { groups were submitted to anamnesis and history of the } \\
\text { complaint, High Frequency Audiometry (HPA), } \\
\text { imitanciometry, acuphenometry, application of THI, } \\
\text { VAS and participated in a counseling session. They } \\
\text { were evaluated before adaptation and after } 3 \text { and } 6 \\
\text { months after adaptation. }\end{array}$ & $\begin{array}{l}\text { The use of SG was equally effective } \\
\text { in treating tinnitus in individuals } \\
\text { with and without hearing loss, } \\
\text { causing an improvement in } \\
\text { disturbance and disability. }\end{array}$ \\
\hline
\end{tabular}




\begin{tabular}{|c|c|c|c|c|}
\hline 12 & 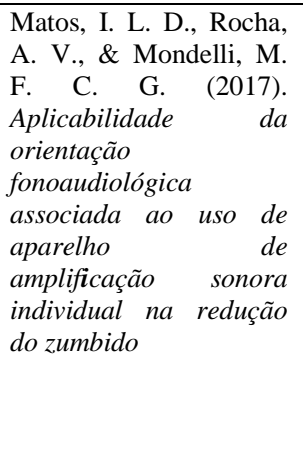 & $\begin{array}{l}\text { To verify the } \\
\text { applicability of speech } \\
\text { therapy guidance } \\
\text { associated with the use } \\
\text { of hearing aids in } \\
\text { reducing the tinnitus } \\
\text { sensation. }\end{array}$ & $\begin{array}{l}\text { Prospective study. } 24 \text { individuals complaining of } \\
\text { continuous tinnitus, diagnosed with mild to moderate } \\
\text { symmetric bilateral sensorineural hearing loss referred } \\
\text { for hearing aid fitting and without prior tinnitus } \\
\text { intervention. } \\
\text { Group A: } 8 \text { individuals fitted with hearing aids, without } \\
\text { guidance regarding tinnitus; } \\
\text { Group B: } 8 \text { individuals fitted with hearing aids, with } \\
\text { guidance through informal conversation; } \\
\text { Group C: } 8 \text { individuals fitted with hearing aids, with } \\
\text { verbal guidance and a booklet. The evaluation was } \\
\text { carried out in } 2 \text { stages: Initial [THI, Selection and } \\
\text { verification of the hearing aid, Orientation] and Final - } \\
\text { three months after using the hearing aid. }\end{array}$ & $\begin{array}{l}\text { All groups showed a reduction in } \\
\text { tinnitus annoyance, and better } \\
\text { results were observed when the } \\
\text { patient received some kind of } \\
\text { guidance about it. Therefore, speech } \\
\text { therapy guidance associated with the } \\
\text { use of hearing aids can favor the } \\
\text { reduction of tinnitus sensation. }\end{array}$ \\
\hline 13 & $\begin{array}{l}\text { Jung M. P., Woo J. K., } \\
\text { Jin B. H., Jung J. H., So } \\
\text { Y.Pa. and Shi N. P. } \\
\begin{array}{lr}(2017) & \\
\text { Effect of r sound } \\
\text { generator on } \\
\text { and hyperacusis }\end{array}\end{array}$ & $\begin{array}{l}\text { To verify the } \\
\text { therapeutic character } \\
\text { of the sound generator } \\
\text { in patients with } \\
\text { tinnitus and with or } \\
\text { without hyperacusis } \\
\text { during the TRT } \\
\text { (Tinnitus Retraining } \\
\text { Therapy) method. }\end{array}$ & $\begin{array}{l}120 \text { tinnitus patients who failed to respond to ambient } \\
\text { sound therapy or patients with distressing hyperacusis } \\
\text { who were subjected to other means of intervention. } \\
\text { Pacients were divided into } 2 \text { groups: Category } 1-78 \\
\text { tinnitus patients who did not have hyperacusis. } \\
\text { Category } 3-42 \text { patients with tinnitus and hyperacusis. } \\
\text { Tonal audiometry, discomfort threshold research, VAS } \\
\text { and THI were performed. Outcomes were evaluated by } \\
\text { comparing LDL, tinnitus, VAS and THI scores before } \\
\text { and after six months of sound generator use, using a t- } \\
\text { test. }\end{array}$ & $\begin{array}{l}\text { The results showed that } 6 \text { months } \\
\text { after using sound generator, there } \\
\text { was improvement in tinnitus. With } \\
\text { this result, the sound generator in } \\
\text { conjunction with the TRT proved to } \\
\text { be an effective treatment for all } \\
\text { patients with tinnitus, especially } \\
\text { those who have hyperacusis as a } \\
\text { comorbidity. }\end{array}$ \\
\hline 14 & $\begin{array}{l}\text { Carol A. Bauer, MD; } \\
\text { Jennifer L. Berry, Aud. } \\
\text { D; Thomas J. Brozoski, } \\
\text { PhD (2017) } \\
\text { The Effect of Tinnitus } \\
\text { Retraining Therapy on } \\
\text { Chronic Tinnitus: A } \\
\text { Controlled Trial }\end{array}$ & $\begin{array}{l}\text { Compare the results of } \\
\text { treatments for chronic } \\
\text { tinnitus annoyance: } \\
\text { Retraining therapy } \\
\text { (TRT) versus standard } \\
\text { treatment care (SC), to } \\
\text { determine the } \\
\text { longevity of the effect } \\
\text { over } 18 \text { months. }\end{array}$ & $\begin{array}{l}\text { Randomized and prospective clinical study. } 39 \\
\text { individuals aged } 18 \text { to } 75 \text { years with chronic tinnitus } \\
\text { and hearing loss subject to rehabilitation with hearing } \\
\text { aids. Participants were divided into } 2 \text { groups: one with } \\
\text { intervention through TRT and the other through } \\
\text { traditional treatment intervention. Both groups used } \\
\text { hearing aids, but only the TRT group received directive } \\
\text { counseling based on TRT and sound generator in the } \\
\text { device. All participants were followed } 1,2 \text { and } 6,12 \\
\text { and } 18 \text { months after the adaptation of the devices. }\end{array}$ & $\begin{array}{l}\text { In this study, both treatments (TRT } \\
\text { and traditional treatment) provided } \\
\text { lasting therapeutic benefit for } \\
\text { individuals with chronic tinnitus. } \\
\text { TRT, however, seemed to be a little } \\
\text { more effective, since participants in } \\
\text { the TRT group had a greater } \\
\text { decrease in THI and a } 50 \% \text { greater } \\
\text { reduction in tinnitus severity } \\
\text { compared to patients who had } \\
\text { access only to traditional treatment. }\end{array}$ \\
\hline 15 & $\begin{array}{l}\text { Rocha, A. V., } \\
\text { \&Mondelli, M. F. C. G. } \\
(2020) . \\
\text { Aplicabilidade das } \\
\text { medidas da orelha real } \\
\text { na intervenção } \\
\text { audiológica do zumbido }\end{array}$ & $\begin{array}{l}\text { To analyze the } \\
\text { applicability of real ear } \\
\text { measurements for } \\
\text { tinnitus audiological } \\
\text { intervention through } \\
\text { specific assessment, } \\
\text { selection, verification } \\
\text { and validation of the } \\
\text { hearing aid combined } \\
\text { with the sound } \\
\text { generator. }\end{array}$ & $\begin{array}{l}\text { Non-randomized clinical trial. } 40 \text { individuals older than } \\
18 \text {, with mild to moderate symmetrical sensorineural } \\
\text { hearing loss and complaint of bilateral chronic tinnitus. } \\
\text { Anamnesis and past history of the complaint, high- } \\
\text { frequency audiometry, immitanciometry and } \\
\text { acuphenometry with depicts research, loudness in this } \\
\text { minimum threshold of masking and sound generator. } \\
\text { The tinnitus handicap inventory (THI) and the visual } \\
\text { analogue scale (EVA) were applied. The entire sample } \\
\text { received hearing aids and a Siemens sound generator } \\
\text { and participated in a counseling session. They were } \\
\text { evaluated before fitting the hearing aids and sound } \\
\text { generator and } 6 \text { months after fitting. }\end{array}$ & $\begin{array}{l}\text { There was benefit from using } \\
\text { hearing aids combined with the } \\
\text { sound generator and strong } \\
\text { correlations between the data from } \\
\text { the sound generator verification } \\
\text { against acuphenometry and the } \\
\text { nuisance/gravity questionnaires. }\end{array}$ \\
\hline 16 & $\begin{array}{l}\text { Mondelli } \\
\text { Cabreira, A.F.; Matos } \\
\text { I.L.; Ferreira M.C.; } \\
\text { Rocha, A. V. (2021) } \\
\text { Sound Generator: } \\
\text { Analysis of the } \\
\text { Effectiveness of Noise in } \\
\text { the Habituation of } \\
\text { Tinitus }\end{array}$ & $\begin{array}{l}\text { To analyze the } \\
\text { effectiveness of four } \\
\text { masking noises in } \\
\text { tinnitus relief in } \\
\text { individuals with mild } \\
\text { and moderate bilateral } \\
\text { sensorineural hearing } \\
\text { loss and their } \\
\text { influence on speech } \\
\text { perception. }\end{array}$ & $\begin{array}{l}35 \text { individuals, aged } 55 \text { to } 70 \text { years, with mild or } \\
\text { moderate bilateral symmetrical sensorineural BP, } \\
\text { complaining of tinnitus for more than six months in } \\
\text { both ears and no previous experience with hearing aids } \\
\text { or SG. Participants were divided into four groups, all } \\
\text { bilaterally adapted with hearing aids and sound } \\
\text { generator, but each group with a different stimulus } \\
\text { (White noise, Pink noise, speech noise and high tone } \\
\text { noise). The subjects underwent audiological evaluation, } \\
\text { application of THI, VAS and psychoacoustic measures } \\
\text { of tinnitus, in addition to HINT. }\end{array}$ & $\begin{array}{l}\text { The four noises were equally } \\
\text { effective in relieving tinnitus, with } \\
\text { no significant differences between } \\
\text { them. Speech perception improved } \\
\text { in the silent speech situation in all } \\
\text { groups, regardless of the noise used. } \\
\text { In the noise situation, the pink noise } \\
\text { showed a significant improvement. }\end{array}$ \\
\hline
\end{tabular}

Source: Research data.

Moura et al. (2004), Silva et al. (2007), Mondelli et al. (2016) and Andersson et al. (2011), in their different studies, had something in common, they assessed hearing aids efficiency in isolation in reducing or eliminating tinnitus in patients with hearing loss. In these four studies, most participants reported tinnitus improvement with hearing aids use, while in some cases, a small part reported no influence whatsoever. Mondelli et al. (2016), also took the opportunity to assess speech perception, and in this situation, there was no significant correlation between speech perception, before and after using hearing aids.

When not used alone, the hearing aid was associated with other resources to aid in the treatment. Among these resources, sound generators, medications and counseling were listed, as well as variations in the type of mold adaptation. 
Of the sixteen studies covered, ten used the sound generator. Of these ten, only three used generators in isolation, being associated exclusively with the hearing aid. The approach in two of these studies was carried out in patients with HL and the other in patients with HL and normal hearing.

Suzuki et al. (2015, evaluated the effectiveness of using the sound generator when individually adjusted in patients with tinnitus unresponsive to previous treatments. Berberian et al. (2016), described the results found in a group of people who underwent treatment with sound generators and Mondelli et al. (2020) analyzed the effectiveness of four different types of masking noise. In these three cases, the results showed a reduction in the tinnitus sensation, with no significant difference regarding the type of noise used.

Two other studies related hearing aids use with sound generators and counseling. Rocha and Mondelli $(2017,2020)$ aimed to verify the effectiveness of SG associated with counseling in individuals with and without hearing loss. In another study, they also analyzed the applicability of real ear measurements for tinnitus audiological intervention in patients with HL, through specific assessment, selection, verification and validation of hearing aid combined with the sound generator and counseling. Again, the result of using the prosthesis with other resources was equally effective in treatment of individuals with and without HL, causing an improvement in the symptom and disability disturbance, when present. Folmer and Carroll (2006) found a similar result, where participants who use hearing aids and sound generators achieved significant reductions in TSI scores (23\% and 17\%, respectively), while a control group, who was not in use of any device, had no significant reduction.

The authors Parazzini et al. (2011), Henry et al. (2015), Bauer et al. (2017) and Park et al. (2017), in turn, decided to investigate hearing aids benefit when related to sound generator and TRT in different formats. The first compared the effectiveness of TRT with SG and TRT with hearing aids in a group of subjects that could be treated both ways. Henry et al. (2006), sought to assess the effectiveness of tinnitus masking and TRT in military personnel with significant tinnitus. Bauer $e t$ al. (2017), compared the outcome of the treatment of chronic tinnitus in a group using TRT and another standard treatment, which involved hearing aids use and counseling, without SG. Finally, Park et al. (2017), chose to verify the therapeutic character of the sound generator in patients with tinnitus and with and without hyperacusis during TRT method.

In these studies, treatments with TRT in its different approaches were effective for all patients with tinnitus, including patients with comorbidities such as hyperacusis. Henry et al found that, when compared to the traditional treatment, without a sound generator, the TRT seemed to be even more effective, since it presented a greater decrease in THI and a greater reduction in the severity of tinnitus. It was also more effective when applied to patients with more severe tinnitus, despite having a slightly slower result, while the SG presented a faster and more satisfactory result when applied to patients with moderate tinnitus.

In the absence of SG, hearing aids are also not typically used in isolation and are provided along with guidance and advice for more effective outcomes (Searchfield et al, 2010). In one of the articles, hearing aid was only associated with counseling by Matos et al., (2017). In this study, the authors sought to verify the effectiveness of speech therapy guidance associated with hearing aids use in reducing tinnitus through the assessment of 3 different groups. The first group contained individuals fitted only with hearing aids, in the second, patients were fitted with hearing aids and received verbal guidance regarding tinnitus, and in the third group, individuals were fitted with hearing aids, verbal guidance and a booklet. In this situation, although all groups presented a reduction in tinnitus discomfort, the best results were when patients received some kind of guidance about it, that is, it was found that the results of the hearing aid regarding the improvement of tinnitus sensation can be even more favorable when associated with good orienteering.

Only one of the articles found sought to relate the type of mold adaptation and tinnitus improvement. In their study, Ferrari et al. (2007) evaluated tinnitus response to an open earmold behind-the-ear hearing aid with relief ventilation in patients with HL after one month of use. Taking into account the short evaluation period, the authors concluded that although most 
patients tested had a significant improvement in tinnitus relief and HL, this improvement did not depend directly on the size of the mold ventilation, at least not in these conditions.

Finally, medication use was also found in only one of the articles. For Oz et al.(2013), the combination of the hearing device with the masking noise of broadband and beta-statin proved to be an effective method. Betastatin is a drug that works by improving blood flow in the inner ear, decreasing pressure buildup and tends to improve symptoms of vertigo and tinnitus.

In general, seven of the sixteen articles surveyed related hearing aid to some type of guidance, either through counseling or the TRT method, we can understand that these two factors combination, speech therapy and hearing aids, can be considered an excellent combination for tinnitus treatment. This combination of features favors its sensation reduction in most cases relatively quickly, efficiently and non-invasively.

\section{Final Considerations}

In summary, the studies used in this review showed a positive result regarding the effectiveness of hearing aids in patients with tinnitus rehabilitation. All studies concluded that somehow, in most of evaluated cases, hearing aid associated or not with other resources used in treatment, contributes to a satisfactory result in relation to symptom improvement or disappearance. None of the articles analyzed showed an opposite or unsatisfactory result regarding its use. More research is needed to understand how hearing aids can be optimized for tinnitus relief.

\section{References}

Andersson, G., Keshishi, A., \& Baguley, D. M. (2011). Benefit from hearing aids in users with and without tinnitus. Audiological Medicine, 9(2), 73-78.

Bauer, C. A., Berry, J. L., \& Brozoski, T. J. (2017). The effect of tinnitus retraining therapy on chronic tinnitus: a controlled trial. Laryngoscope investigative otolaryngology, 2(4), 166-177.

Berberian, A. P., Ribas, A., Imlau, D., Guarinello, A. C., Massi, G., Tonocchi, R., ... \& Rosa, M. R. D. (2016). Benefit of using the prosthesis with sound generators in individuals with tinnitus associated with mild to moderately severe hearing loss. The international tinnitus journal, 20 (2), 64-68.

Brennan-Jones, C. G., Thomas, A., Hoare, D. J., \& Sereda, M. (2020). Cochrane corner: Sound therapy (using amplification devices and/or sound generators) for tinnitus. International journal of audiology, 59(3), 161-165.

Ferrari, G. M. S., Sanchez, T. G., \& Bernardi, A. P. A. (2003). O controle do zumbido através do uso de próteses auditivas retro-auriculares. Rev. CEFAC, 5(2).

Ferrari, G. M. D. S., Sanchez, T. G., \& Pedalini, M. E. B. (2007). A eficácia do molde aberto para o controle do zumbido. Revista Brasileira de Otorrinolaringologia, 73, 370-377.

Folmer, R. L., \& Carroll, J. R. (2006). Long-term effectiveness of ear-level devices for tinnitus. Otolaryngology-Head and Neck Surgery, 134(1), 132-137.

Henry, J. A., Schechter, M. A., Zaugg, T. L., Griest, S., Jastreboff, P. J., Vernon, J. A., ... \& Stewart, B. J. (2006). Clinical trial to compare tinnitus masking and tinnitus retraining therapy. Acta Oto-Laryngologica, 126(sup556), 64-69.

Holdefer, L., de Oliveira, C. A. C., \& Venosa, A. R. (2010). Sucesso no tratamento do zumbido com terapia em grupo. Brazilian Journal of Otorhinolaryngology, 76, 102-106.

Jastreboff, P. J., \& Jastreboff, M. M. (2000). Tinnitus retraining therapy (TRT) as a method for treatment of tinnitus and hyperacusis patients. Journal of the American Academy of Audiology, 11(3), 162-177.

Knobel, K., \& Almeida, K. (2001). Perfil dos pacientes em terapia para habituação do zumbido (TRT). Fonoaudiologia Brasil, 1(2), $33-43$.

Matos, I. L. D., Rocha, A. V., \& Mondelli, M. F. C. G. (2017). Aplicabilidade da orientação fonoaudiológica associada ao uso de aparelho de amplificação sonora individual na redução do zumbido. Audiology-Communication Research, 22.

Mondelli, M. F. C. G., Cabreira, A. F., Matos, I. L. D., Ferreira, M. C., \& Rocha, A. V. (2021). Sound Generator: Analysis of the Effectiveness of Noise in the Habituation of Tinnitus. International Archives of Otorhinolaryngology, 25, 205-212.

Mondelli, M. F. C. G., Argentim, J. P., \& Rocha, A. V. (2016). Correlação entre percepção de fala e zumbido antes e após o uso de amplificação. AudiologyCommunication Research, 21

Moura, L. O. S. D., Iório, M. C. M., \& Azevedo, M. F. D. (2004). A eficácia da adaptação de prótese auditiva na redução ou eliminação do zumbido. Revista Brasileira de Otorrinolaringologia, 70, 624-631. 
Research, Society and Development, v. 11, n. 1, e11211124266, 2022

(CC BY 4.0) | ISSN 2525-3409 | DOI: http://dx.doi.org/10.33448/rsd-v11i1.24266

Oz, I., Arslan, F., Hizal, E., Erbek, S. H., Eryaman, E., Senkal, O. A., ... \& Ozluoglu, L. N. (2013). Effectiveness of the combined hearing and masking devices on the severity and perception of tinnitus: a randomized, controlled, double-blind study. Orl, 75(4), 211-220.

Padilha, C. B. (2006). Zumbido: abordagem teórica.

Park, J. M., Kim, W. J., Ha, J. B., Han, J. J., Park, S. Y., \& Park, S. N. (2018). Effect of sound generator on tinnitus and hyperacusis. Acta otolaryngologica, 138(2), 135-139.

Parazzini, M., Del Bo, L., Jastreboff, M., Tognola, G., \& Ravazzani, P. (2011). Open ear hearing aids in tinnitus therapy: An efficacy comparison with sound generators. International journal of audiology, 50(8), 548-553.

Rocha, A. V., \& Mondelli, M. F. C. G. (2017). Sound generator associated with the counseling in the treatment of tinnitus: evaluation of the effectiveness 计. Brazilian Journal of Otorhinolaryngology, 83, 249-255.

Rocha, A. V., \& Mondelli, M. F. C. G. (2020). Applicability of the real ear measurement for audiological intervention of tinnitus 幽, 记坛. Brazilian journal of otorhinolaryngology, 86, 14-22.

Rosa, M. R. D. D., Almeida, A. A. F. D., Pimenta, F., Silva, C. G., Lima, M. A. R., \& Diniz, M. D. F. F. M. (2012). Zumbido e ansiedade: uma revisão da literatura. Revista Cefac, 14, 742-754.

Sanchez, T. G., Pedalini, M. E. B., \& Bento, R. F. (2002). Aplicação da terapia de retreinamento do zumbido (TRT) em hospital público. Arq Int Otorrinolaringol, 6(1), 29-38.

Searchfield, G. D., Kaur, M., \& Martin, W. H. (2010). Hearing aids as an adjunct to counseling: tinnitus patients who choose amplification do better than those that don't. International journal of audiology, 49(8), 574-579.

Suzuki, F. A. D. B., Suzuki, F. A., Yonamine, F. K., Onishi, E. T., \& Penido, N. O. (2016). Effectiveness of sound therapy in patients with tinnitus resistant to previous treatments: importance of adjustments 2 . Brazilian Journal of otorhinolaryngology, 82, 297-303.

Tyler, R. S., Pienkowski, M., Roncancio, E. R., Jun, H. J., Brozoski, T., Dauman, N., ... \& Moore, B. C. (2014). A review of hyperacusis and future directions: part I. Definitions and manifestations. American journal of audiology, 23(4), 402-419.

Tunkel, D. E., Bauer, C. A., Sun, G. H., Rosenfeld, R. M., Chandrasekhar, S. S., Cunningham Jr, E. R., \& Whamond, E. J. (2014). Clinical practice guideline: tinnitus. Otolaryngology-Head and Neck Surgery, 151(2_suppl), S1-S40. 